\title{
Plasmid and chromosomal related toxin polymorphism of Escherichia coli serogroup 0138; plasmid transfer and co-integration with $\mathrm{pRP} 4$
}

\author{
M. J. WOODWARD, C. WRAY, G. A. RIDHA* and J. R. WALTON*
}

Department of Bacteriology, MAFF Central Veterinary Laboratory, New Haw, Weybridge, Surrey KT15 3NB and 'Department of Veterinary Clinical Science, University of Liverpool, Leahurst Field Station, Neston, South Wirral L64 7TE

\begin{abstract}
Summary. DNA-DNA hybridisation was used to examine 89 isolates of Escherichia coli serogroup $\mathrm{O} 138$ for toxin gene content and location. Sixty-six isolates encoded toxin genes; 29 were STpa STpb VT2, 24 were VT2, four were STpa STpb, three were STpb VT2, three were STpb VT2 LT and one was STpa. None were K88-, K99- or F41-positive. The VT toxin gene was chromosomally located in all $\mathrm{VT}^{+}$isolates tested whereas STpa, STpb and LT were plasmid borne. In co-transfer experiments with pRP4 as the mobilising plasmid, VT2 genes were not transferred to recipient $E$. coli $\mathrm{K} 12$ whereas STpa, STpb and LT genes were. Two VT2-positive isolates inhibited pRP4 transfer to K12 by a factor of $10^{6}$ and rare transconjugants harboured a cointegrate plasmid comprising pRP4 (54kb) and a cryptic host plasmid (145 kb). In a $\mathrm{K} 12$ background, the co-integrate had transfer and incompatibility properties of pRP4 whereas in both progenitor E. coli $\mathrm{O} 138$ backgrounds the co-integrate was transfer inhibited and in one case resolved to give original plasmids.
\end{abstract}

\section{Introduction}

Escherichia coli serotype O138: $\mathrm{K} 81$ has long been associated with oedema disease and post-weaning diarrhoea in pigs (Sojka et al., 1957). This serotype has subsequently been shown to be present in pigs in many countries (Sojka, 1965). Oedema disease is a toxaemic disease (Sojka, 1965) and many of the classical $E$. coli strains associated with the disease produce a toxin that causes a cytoxic effect in Vero cells (Smith et al., 1983). Likewise Dobrescu (1983) and Linggood and Thompson (1987) examined a number of oedema disease-producing strains of E. coli; although VT was detected, other E. coli enterotoxins were uncommon. During the development of gene probes for the detection of $E$. coli toxins in this laboratory, it was observed that some strains of $E$. coli $\mathrm{O} 138: \mathrm{K} 81$ produced a wide range of toxins (Woodward et al., in press). Transmissible plasmids encoding combinations of enterotoxin and adhesin genes have been described (Smith et $a l ., 1985)$ and it seems likely that toxin polymorphism might be attributed to possession of such plasmids. However, Gannon et al. (1988) were unable to demonstrate transmissibility of genes encoding verocytotoxin from verocytotoxigenic

Received 26 July 1989; accepted 23 Aug. 1989.
$E$. coli isolates from pigs. The porcine verocytotoxin, also referred to as Shiga-like toxin II variant (SLT-IIV) by Marques et al. (1987) is antigenically distinct from the human verocytotoxins, VT1 and VT2 (Law, 1988; Smith and Scotland, 1988; Karmali, 1989) but the gene encoding porcine verocytotoxin shows significant DNA sequence homology with VT2 (Smith et al., 1988). The location of SLT-IIV genes is unknown whereas VT1 and VT2 genes were isolated from temperate bacteriophages in E. coli of serogroup $\mathrm{O} 157$ isolated from man (Willshaw et al., 1985, 1987). In this paper, we report our initial studies aimed at understanding the genetic basis of toxin polymorphism in E. coli serogroup O138, which may assist in elucidation of the aetiology of the economically important disease of post-weaning diarrhoea.

\section{Materials and methods}

\section{Bacterial strains and plasmids}

$E$. coli strains isolated from pigs with intestinal infection during the period 1986-1989 were stored on Dorset egg slopes (PM5; Oxoid) at room temperature. All isolates were serotyped and tested for the presence of adhesins by standard methods based on those of Sojka (1965). Those belonging to serogroup $\mathrm{O} 138$ were plated 
on blood agar and individual colonies were used in DNADNA hybridisation or plasmid profiling. E. coli K12 strains were $5 \mathrm{~K} \mathrm{~F}^{-}$thr leu lac $\mathrm{Y}$ ton $\mathrm{A} 21$ hsd $\mathrm{RS} 14$ rpsL thil (Colson et al., 1965), J62 $\mathrm{F}^{-}$lac pro his trp, and J62.1 $\mathrm{F}^{-}$lac pro his trp nal. Plasmids were $\mathrm{pRP} 4 \mathrm{Ap} \mathrm{Km} \mathrm{Tc}$ inc $\mathrm{P} 54 \mathrm{~kb}$ and $\mathrm{pR} 751 \mathrm{Tp}$ inc $\mathrm{P} 45 \mathrm{~kb}$ (National Collection of Type Cultures, plasmid section, Central Public Health Laboratory, Colindale, London).

\section{Plasmid profiles}

Plasmids were extracted by the alkaline lysis method of Birnboim and Doly (1979) and lysates were subjected to agarose $0.7 \%$ gel electrophoresis with TAE buffer (40 mM Tris, 5 mM sodium acetate, $1 \mathrm{~mm}$ EDTA, pH 7.6) at $3 \mathrm{~V} / \mathrm{cm}$ at $4^{\circ} \mathrm{C}$. Gels were stained in TAE buffer containing ethidium bromide $0.5 \mu \mathrm{g} / \mathrm{ml}$ for $40 \mathrm{~min}$ and destained in distilled water for $10 \mathrm{~min}$ before visualisation under UV illumination.

\section{Colicin sensitivity testing}

The overlay and mitomycin C-induction of colicin techniques of Pugsley and Oudega (1987) were used.

\section{Conjugation}

Conjugation experiments were performed as described previously (Woodward et al., 1989a).

\section{DNA-DNA hybridisation}

Derivation of gene probes. The LT probe was a 750-bp HindIII fragment derived from pEWD299 (Dallas et al., 1979). The STpa probe had a 157-bp HinfI fragment derived from pRIT10036, formerly pCLS2 (Lathe et al., 1980; Moseley et al., 1980). The STpb probe was a 460bp HinfI fragment derived from the smaller of two HindIII fragments of pRAS, formerly pCHL6 (Lee et al., 1983). The VTI probe was a 530-bp HindIII/AccI fragment derived from pNTP705 (Willshaw et al., 1985). The VT2 probe was a 660-bp EcoRV/HincII fragment derived from pNTP707 (Willshaw et al., 1987). The K99 probe was a 1250-bp $B g / \mathrm{II} / S m a I$ fragment derived from pFK99 (de Graaf et al., 1984). The K88 probe was a 1700-bp EcoRI fragment derived from pFM205 (Moseley et al., 1986). The F41 probe was a $660 \mathrm{bp} \mathrm{HincII/SaII}$ fragment derived from pDGA9 (Anderson and Moseley, 1988).

Probe preparation. Probe fragments were purified by electro-elution of DNA-containing bands cut from agarose (if more than $500 \mathrm{bp}$ ) or polyacrylamide (if less than $500 \mathrm{bp}$ ) gels of restriction enzyme digests. After electro-elution, probe DNA fragments were washed successively in phenol, phenol:chloroform $1: 1$ and chloroform (Maniatis et al., 1982) and concentrated by precipitation under 2.5 volumes of absolute ethanol at $-70^{\circ} \mathrm{C}$ after addition of sodium acetate to $150 \mathrm{~mm}$. Probe DNA was radiolabelled to about $1 \times 10^{9} \mathrm{cpm} / \mu \mathrm{g}$ specific activity with $\alpha^{32} \mathrm{PdCTP}$ by random hexanucleotide primer DNA synthesis (Multiprime, Amersham) as described by Feinberg and Vogelstein (1983).

Colony lysis. Cultures for testing were grown overnight in Brain-Heart Infusion broth at $37^{\circ} \mathrm{C}$ with agitation. From each culture, $5 \mu$ l were transferred to the surface of a nylon membrane (Hybond- $\mathrm{N}$, Amersham) overlaid on a dried MacConkey agar plate. Inoculated filters were incubated at $37^{\circ} \mathrm{C}$ for $4 \mathrm{~h}$. Colonies from conjugation experiments were transferred to nylon membranes by replica plating. Colonies were lysed by laying filters colony side up sequentially on blotting paper saturated with SDS $5 \%$ for $5 \mathrm{~min}, 0.5 \mathrm{M} \mathrm{NaOH}, 1.5 \mathrm{M} \mathrm{NaCl}$ for 15 $\min$ and $1.5 \mathrm{M} \mathrm{NaCl}, 1.0 \mathrm{M}$ Tris- $\mathrm{HCl}, \mathrm{pH} 7$ for two $7-\mathrm{min}$ periods based on the technique of Mainil et al. (1985). Air dried filters were wrapped in Saran wrap and exposed to UV irradiation ( $302 \mathrm{~nm}$ ) by inversion over a transilluminator (Ultra Violet Product Inc.) for $4 \mathrm{~min}$ to fix the DNA.

Hybridisation. When probing for LT, STpa or STpb genes, filters were prehybridised for at least $1 \mathrm{~h}$ at $65^{\circ} \mathrm{C}$ in $6 \times \operatorname{SSC}(1 \times \mathrm{SSC}$ is $0.15 \mathrm{M} \mathrm{NaCl}, 0.015 \mathrm{M}$ sodium citrate, $\mathrm{pH} 7), 5 \times$ Denhardt's solution $(1 \times$ Denhardt's is bovine serum albumin (Pentax fraction V) $0.02 \% \mathrm{w} / \mathrm{v}$, Ficoll $\mathrm{Mr} 400000 \quad 0.02 \% \mathrm{w} / \mathrm{v}$, polyvinylpyrolidone $\mathrm{Mr}$ $3600000.02 \%$ and SDS $0.5 \% \mathrm{w} / \mathrm{v}$ containing sonicated heat denatured salmon sperm DNA (Sigma) $20 \mu \mathrm{g} / \mathrm{ml}$. When probing for VT1, VT2, K99, K88 or F41 genes, filters were prewashed at $42^{\circ} \mathrm{C}$ for $2 \mathrm{~h}$ in $50 \mathrm{mM}$ Tris$\mathrm{HCl}, \mathrm{pH} 8.0,1 \mathrm{M} \mathrm{NaCl}, 1 \mathrm{~mm}$ EDTA and SDS $0.1 \%$ followed by prehybridisation for $4 \mathrm{~h}$ at $42^{\circ} \mathrm{C}$ in formamide $50 \% \mathrm{v} / \mathrm{v}, 5 \times \operatorname{SSPE}(1 \times \mathrm{SSPE}$ is $0.18 \mathrm{M} \mathrm{NaCl}, 10 \mathrm{mM}$ $\mathrm{NaH}_{2} \mathrm{PO}_{4}, 1 \mathrm{~mm}$ EDTA), $5 \times$ Denhardt's solution and SDS $0.1 \% \mathrm{w} / \mathrm{v}$ containing sonicated heat denatured salmon sperm DNA $100 \mu \mathrm{g} / \mathrm{ml}$. Radiolabelled probes were denatured at $100^{\circ} \mathrm{C}$ for $2 \mathrm{~min}$ then immediately placed in ice and added to the filters $(10 \mathrm{ng}$ of probe DNA per $10 \mathrm{~cm} \times 10 \mathrm{~cm}$ filter) in fresh hybridisation solution. The probes were allowed to hybridise for $16 \mathrm{~h}$; hybridisations with LT, STpa and STpb were performed at $65^{\circ} \mathrm{C}$ and those with VT1, VT2, K99, K88 and F41 at $42^{\circ} \mathrm{C}$. Post-hybridisation stringency washes for all probes were in $2 \times \operatorname{SSC}$, SDS $0.1 \%$ at room temperature $(4 \times 10$ $\min ), 1 \times \mathrm{SSC}$, SDS $0.1 \%$ at $68^{\circ} \mathrm{C}(2 \mathrm{~h})$ and $0.2 \times \mathrm{SSC}$, SDS $0.1 \%$ at $68^{\circ} \mathrm{C}(1 \mathrm{~h})$. After air drying, filters were exposed to X-ray film (Fuji RX) with intensifying screens (Cronex) at $-70^{\circ} \mathrm{C}$.

\section{Results}

\section{Toxin profile of E. coli $O 138$ strains}

Porcine $E$. coli isolates belonging to serogroup O138:K81, which had been stored in the E. coli reference laboratory at the Central Veterinary Laboratory since 1986, were tested for the presence of toxin genes by DNA hybridisation. Of the 89 isolates, two were isolated from 1-month-old piglets with systemic disease, one was from an adult pig 
with diarrhoea and the remainder were from postweaning piglets aged 4-7 weeks. Sixty-six isolates were shown to harbour at least one toxin gene; 29 were STpa, STpb, VT2 positive, 24 were VT2 positive, four were STpa, STpb positive, three were STpb, VT2 positive, three were STpb, VT2, LT positive and one was STpa positive. The two isolates from systemic disease were STpa STpb positive and STpa STpb VT2 positive respectively. None of the isolates produced K99, F41 or K88 fimbriae as determined by either agglutination tests or by hybridisation with adhesin specific gene probes.

\section{Location of toxin genes}

The location of toxin genes on plasmids and their transmissibility in vitro has been well documented (Smith et al., 1985). However, the question remains as to why E. coli serogroup O138 demonstrates considerable diversity with respect to toxin type and the combinations of toxins produced. To locate the toxin genes, Southern transfers of plasmid profiles of 24 isolates representing each of the toxin combination genotypes were tested by hybridisation with each toxin gene probe. The results are given in table I. All isolates harboured at least one plasmid with as many as seven in two isolates. The method for plasmid extraction was that of Birnboim and Doly (1979) and a considerable chromosomal smear was always present as demonstrated by visualisation of ethidium bromide staining of agarose gel electrophoresis separated cell lysates. Without exception, the VT2 probe hybridised with the chromosomal smear of all $15 \mathrm{VT}^{+}$isolates tested. Probes specific for STpa, STpb and LT hybridised with plasmid DNA but only with a single plasmid in any one isolate. Within any one toxin genotype, common toxin bearing plasmids were detected such as a 112-kb STpb LT, plasmid in the three STpb LT VT2 isolates tested, a 120-kb STpa STb plasmid in three of five and a $125-\mathrm{kb}$ STpa STpb plasmid in two of five STpa STpb VT2 isolates and a 112-kb STpa STpb plasmid in three of four STpa STpb isolates.

\section{Transmissibility of toxin genes}

To test for transmissibility of toxin genes, filter mating experiments were set up. However, direct selection for transfer of toxin genes was not possible. Therefore, to demonstrate that gene transfer had occurred in any filter mating with an $\mathrm{O} 138$ donor and $\mathrm{K} 12$ recipient, co-transfer experiments were

Table I. Plasmid profiles of toxigenic E. coli of serogroup O138 and location of toxin genes

\begin{tabular}{|c|c|c|c|c|}
\hline Isolate no. & $\begin{array}{l}\text { Toxin genes } \\
\text { encoded }\end{array}$ & $\begin{array}{l}\text { Number of } \\
\text { plasmids }\end{array}$ & $\begin{array}{l}\text { Approximate size } \\
\text { of plasmids }(\mathrm{kb})\end{array}$ & Location of toxin gene \\
\hline M470-86 & VT2 & 3 & $165,90,22$ & $\operatorname{chr}(\mathrm{VT} 2)$ \\
\hline M471-86 & VT2 & 3 & $165,90,22$ & $\operatorname{chr}(\mathrm{VT} 2)$ \\
\hline M140-87 & VT2 & 4 & $145,120,6.9$ & chr (VT2) \\
\hline M634-86 & VT2 & 6 & $120,115,90$ & $\operatorname{chr}(\mathrm{VT} 2)$ \\
\hline M160-87 & VT2 & 6 & $145,105,6.9$ & $\operatorname{chr}$ (VT2) \\
\hline M213-86 & STpa & 3 & $120,90,60$ & 120 (STpa) \\
\hline M426-86 & STpb & 4 & $120,90,57,6$ & $90(\mathrm{STpb})$ \\
\hline M269-87 & $\mathrm{STpb}$ & 3 & $150,90,72$ & $90(\mathrm{ST} p \mathrm{p})$ \\
\hline M $25-86$ & STpa STpb VT2 & 2 & 165,120 & $\operatorname{chr}(\mathrm{VT} 2) 120(\mathrm{STpa}$ STpb) \\
\hline M $49-86$ & STpa STpb VT2 & 3 & $165,125,9$ & $\operatorname{chr}$ (VT2) 125 (STpa STpb) \\
\hline M $91-86$ & STpa STpb VT2 & 2 & 165,120 & $\operatorname{chr}$ (VT2) 120 (STpa STpb) \\
\hline M101-86 & STpa STpb VT2 & 5 & $165,120,51,5 \cdot 7,4 \cdot 5$ & chr (VT2) 120 (STpa STpb) \\
\hline M500-88 & STpa STpb VT2 & 4 & $170,125,69,6$ & chr (VT2) 125 (STpa STpb) \\
\hline M243-87 & STpb VT2 & 5 & $160,128,82,6 \cdot 2,6$ & $\operatorname{chr}(\mathrm{VT} 2) 82(\mathrm{STpb})$ \\
\hline M627-86 & STpb VT2 & 7 & $160,115,110,90,67,64,5 \cdot 4$ & $\operatorname{chr}$ (VT2) 90 (STpb) \\
\hline M 92-88 & STpa STpb & 4 & $120,112,52,30$ & 112 (STpa STpb) \\
\hline M108-88 & STpa STpb & 1 & 112 & $112($ STpa STpb) \\
\hline M458-88 & STpa STpb & 7 & $160,135,112,60,7 \cdot 5,7,6 \cdot 3$ & 112 (STpa STpb) \\
\hline M136-86 & STpa STpb & 5 & $150,142,45,5 \cdot 3,4 \cdot 5$ & $142(\mathrm{ST}$ pa STpb) \\
\hline M576-86 & STpb LT VT2 & 2 & 112,36 & $\operatorname{chr}(\mathrm{VT} 2) 112(\mathrm{STpb} \mathrm{LT})$ \\
\hline M419-88 & STpb LT VT2 & 4 & $157,112,30,5 \cdot 9$ & $\operatorname{chr}(\mathrm{VT} 2) 112$ (STpb LT) \\
\hline M421-88 & STpb LT VT2 & 4 & $157,112,30,5.9$ & $\operatorname{chr}(\mathrm{VT} 2) 112$ (STpb LT) \\
\hline
\end{tabular}

Location of genes was determined by DNA hybridisation with Southern blot of plasmid profiles; chr, chromosomal DNA; size (in $\mathrm{kb}$ ) indicates the plasmid that gave the hybridising signal. 
performed in which the donor carried a promiscuous selectable plasmid. Transconjugants were then probed for the presence of toxin genes. The inc $\mathrm{P}$ plasmid, $\mathrm{pRP} 4$, was introduced by filter mating into representative antibiotic-sensitive $\mathrm{O} 138$ isolates. The donor was strain J62pRP4 and selection was made on glucose minimal medium containing kanamycin $40 \mu \mathrm{g} / \mathrm{ml}$. The frequencies of transfer were satisfactory, being between $2 \times 10^{-2}$ and $6 \times$ $10^{-5}$ /donor compared with $10^{-1}$ /donor in a $\mathrm{K} 12$ to $\mathrm{K} 12$ control mating. Derivatives of isolates M14087(VT2), M160-87(VT2), M245-87(STpa), M26987(STpb), M25-86 (STpa STpb VT2), M243-87 (STpb VT2), M458-88 (STpa STpb) and M576-86 (STpb LT VT2) bearing pRP4 did not grow when plated on glucose minimal medium containing streptomycin $500 \mu \mathrm{g} / \mathrm{ml}$ and in filter matings of the form M140-87pRP4 $\times E$. coli K12 strain $5 \mathrm{~K}$ thr leu thi rps $\mathrm{L}$ selection was made on glucose minimal medium supplemented with thiamine $20 \mu \mathrm{g} / \mathrm{ml}$, threonine $50 \mu \mathrm{g} / \mathrm{ml}$ and leucine $50 \mu \mathrm{g} / \mathrm{ml}$ and to which kanamycin $40 \mu \mathrm{g} / \mathrm{ml}$ and streptomycin $500 \mu \mathrm{g} / \mathrm{ml}$ were added as counterselective agents. The frequencies of pRP4 transfer are given in table II. With the exceptions of isolates M140-87 and M160-87, pRP4 transfer ranged from $10^{-3}$ to $10^{-4}$ although this was markedly less than for $\mathrm{K} 12$ to K 12 transfer. Nylon membranes were overlaid on selection plates and the colonies were removed and the cells were lysed. These colony blots were allowed to hybridise with the relevant toxin gene probe (table II). The apparent frequency of transfer of a toxin gene was calculated from the number of hybridisation-positive colonies against the dilution

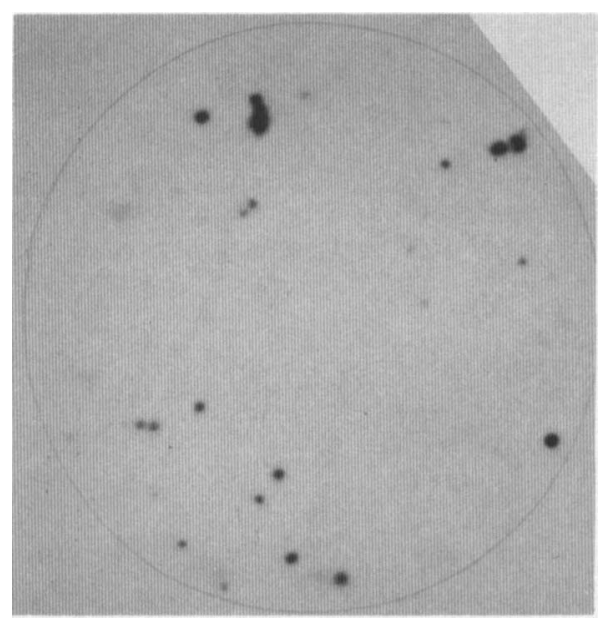

Fig. 1. Autoradiograph showing the hybridisation of the STpaspecific gene probe with transconjugant colonies which had been replicated and lysed on a nylon membrane. The mating was of isolate M245-87 pRP4 (STpa ${ }^{+}$) with strain $5 \mathrm{~K}$, with selection for transfer of pRP4 on counterselective media containing kanamycin spread with undiluted mating mixture to give confluent growth; the resultant colonies were transferred to a nylon membrane by replica plating and lysed with $0.5 \mathrm{M} \mathrm{NaOH}$ before hybridisation.

factor from which the membrane was prepared. An example of an autoradiograph from which data was obtained is shown in fig. 1. The gene encoding VT'2 was not transferred in any experiment. Where the donor harboured a multiple toxin plasmid (M2586, M458-88, M576-86), the frequencies of transfer of each toxin from any one donor were identical and the same transconjugant colonies hybridised,

Table II. Plasmid and toxin gene transfer from E. coli of serogroup 0138

\begin{tabular}{|c|c|c|c|c|c|}
\hline \multirow{2}{*}{$\begin{array}{l}\text { pRP4 harbouring } \\
\text { O1 } 38 \text { derivatives and } \\
\text { toxin genotype }\end{array}$} & \multirow{2}{*}{$\begin{array}{c}\begin{array}{c}\text { Frequency of pRP4 } \\
\text { transfer into } E . \text { coli } \\
\text { strain }\end{array} \\
\mathrm{K} 125 \mathrm{~K}\end{array}$} & \multicolumn{4}{|c|}{$\begin{array}{c}\text { Frequency of transfer of toxin genes as } \\
\text { determined by DNA hybridisation of pRP4 } \\
\text { transconjugants }\end{array}$} \\
\hline & & VT2 & STpa & STpb & LT \\
\hline $\begin{array}{l}\text { M140-87 (VT2) } \\
\text { M160-87 (VT2) } \\
\text { M245-87 (STpa) } \\
\text { M269-87 (STpb) } \\
\text { M25-86 (STpa STpb VT2) } \\
\text { M243-87 (STpb VT2) } \\
\text { M458-88 (STpa STpb) } \\
\text { M576-86 (STpb LT VT2) } \\
\text { E. coli K2 J62 }\end{array}$ & $\begin{array}{c}5 \times 10^{-8 *} \\
8 \times 10^{-8 *} \\
4 \times 10^{-4} \\
6 \times 10^{-4} \\
3 \times 10^{-4} \\
6 \times 10^{-3} \\
6 \times 10^{-3} \\
8 \times 10^{-4} \\
1.1 \times 10^{-1}\end{array}$ & $\begin{aligned}< & 10^{-9} \\
< & 10^{-9} \\
& \cdots \\
& \cdots \\
< & 10^{-9} \\
< & 10^{-9} \\
& \cdots \\
< & 10^{-9} \\
& \ldots\end{aligned}$ & $\begin{array}{c}\cdots \\
7 \times 10^{-7} \\
\cdots \\
6 \times 10^{-7} \\
\cdots \\
4 \times 10^{-7} \\
\cdots \\
\cdots\end{array}$ & $\begin{array}{c}\cdots \\
\cdots \\
8 \times 10^{-7} \\
6 \times 10^{-7} \\
6 \times 10^{-6} \\
4 \times 10^{-7} \\
1 \times 10^{-8} \\
\cdots\end{array}$ & $\begin{array}{c}\cdots \\
\cdots \\
\cdots \\
\cdots \\
\cdots \\
\cdots \\
1 \times 10^{-8} \\
\ldots\end{array}$ \\
\hline
\end{tabular}

* Only 63 transconjugants from three separate mating experiments were obtained and none hybridised with the VT2 toxin gene probe. 
suggesting transfer en bloc. The frequencies of toxin transfer were (in general) about $10^{-3}$-fold less that of pRP4, which suggests that the toxin genes were not carried by highly promiscuous plasmids. The inability to pick transconjugant colonies from confluent replica plates and the destructive nature of the hybridisation protocol precluded the isolation of transconjugants to determine whether toxin genes had been mobilised with pRP4 as entire autonomous plasmids, or as co-integrates or had transposed on to $\mathrm{pRP} 4$.

\section{The effect of colicins upon plasmid transfer}

The transfer of pRP4 from E. coli $\mathrm{K} 12$ into $\mathrm{O} 138$ isolates and the subsequent transfer of pRP4 from O138 transconjugants back into $E$. coli $\mathrm{K} 12$ may have been hindered by killing of $E$. coli $\mathrm{K} 12$ by colicins produced by $\mathrm{O} 138$ isolates. Indeed, plasmid profiles showed that 12 of the $24 \mathrm{O} 138$ isolates harboured small plasmids (4-8 kb in size) which may encode colicins (Pugsley and Oudega, 1987). The overlay technique and mitomycin $\mathrm{C}$ induced cell lysate technique demonstrated that $E$. coli $\mathrm{K} 12$ strain $5 \mathrm{~K}$, used as the recipient in mating experiments, was killed by M25-86, M140-87, M160-87, M243-87 and M458-88. The question arose as to whether the killing effect, whether or not the result of colicin or bacteriophage activity, was sufficient to explain the dramatic decrease in pRP4 transfer from strains M140-87 and M160-87 to E. coli K12 strain 5K. Repeat mating experiments were set up with strains M140-87 pRP4 and M160-87 pRP4 as donors with strain $5 \mathrm{~K}$ as recipient, and selection was made for strain $5 \mathrm{~K}$ alone on minimal medium supplemented with streptomycin. The number of strain $5 \mathrm{~K}$ surviving was about $4 \times 10^{7} /$ filter compared with $2 \times 10^{8} /$ filter in a control experiment with strain J62pRP4 as donor and strain $5 \mathrm{~K}$ as recipient. Twenty-four surviving colonies of strain $5 \mathrm{~K}$ from each of the experiments with pRP4positive isolates M140-87, M160-87 and J62pRP4 as donor were screened for plasmid content; those with strains M140-87 and M160-87 as donor had received a $6.9-\mathrm{kb}$ plasmid whereas no other plasmids were detected in $5 \mathrm{~K}$ recipients from any donor. It is possible that the $6 \cdot 9-\mathrm{kb}$ plasmid conferred colicin (or bacteriophage immunity) resulting in survival of the cells of strain $5 \mathrm{~K}$.

\section{Stable cointegrate formation with pRP4}

The very low frequency of transfer of pRP4 from isolates M140-87 and M160-87 to strain K12 may have been caused by some active mechanism, perhaps fertility inhibition. Plasmid profiles of isolates M140-87, M160-87, pRP4 derivatives and $5 \mathrm{KpRP} 4$ transconjugants were prepared (fig. 2, lanes 6-12). Isolate M140-87 harboured two large plasmids of about $145 \mathrm{~kb}$ and $120 \mathrm{~kb}$ (lane 12) and isolate M160-87 harboured two large plasmids of about $145 \mathrm{~kb}$ and $105 \mathrm{~kb}$ (lane 11). Both isolates

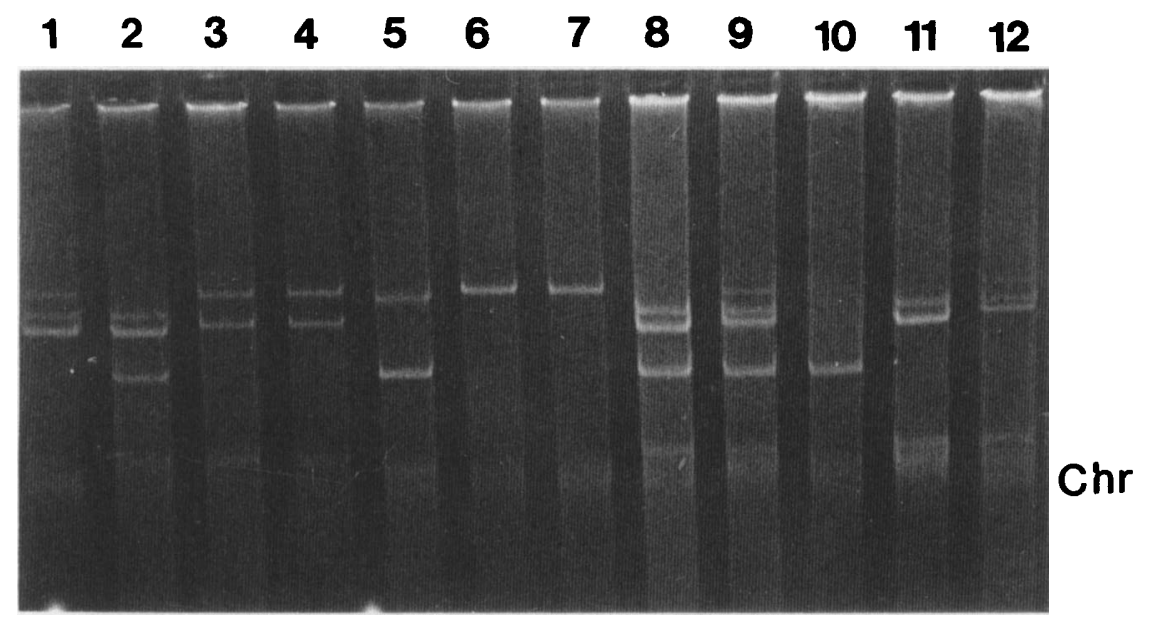

Fig. 2. Cell lysates of $E$. coli $\mathrm{O} 138$ strains and derivatives run through agarose $0 \cdot 7 \%$ and visualised under transillumination after ethidium bromide staining: M140-87 (lane 12); M160-87 (lane 11); J62 pRP4 Ap ${ }^{\mathrm{r}} \mathrm{Tc}^{\mathrm{r}} \mathrm{Km}^{\mathrm{r}}$ (lane 10); M140-87 pRP4 (lane 9); M160-87 pRP4 (lane 8); $5 \mathrm{~K} \mathrm{Ap}{ }^{r} \mathrm{Tc}^{\mathrm{r}} \mathrm{Km}^{\mathrm{r}}$, transconjugant designated 140.2, derived from a mating with M140-87 pRP4 as donor (lane 7); $5 \mathrm{~K} \mathrm{Ap}{ }^{r} \mathrm{Tc}^{\mathrm{r}} \mathrm{Km}^{\mathrm{r}}$ transconjugant, designated $160 \cdot 2$, derived from a mating with M160-87 pRP4 as donor (lane 6); E. coli $\mathrm{K} 12$ plasmid mol. wt reference strain harbouring plasmids of $170 \mathrm{~kb}$ and $56 \mathrm{~kb}$ (lane 5); M160-87 Ap $\mathrm{Tc}^{\mathrm{r}} \mathrm{Km}^{\mathrm{r}}$ transconjugants derived from a mating with $160 \cdot 2$ as donor (lane 3 and 4); M140-87 $\mathrm{Ap}^{r} \mathrm{Tc}^{r} \mathrm{Km}^{r}$ transconjugants derived from a mating with $140 \cdot 2$ as donor (lanes 1 and 2). Chromosomal DNA is indicated by chr. 
M140-87 and M160-87 harboured a 6.9-kb putative colicin plasmid (not shown). Derivatives of isolates M140-87 and M160-87 harbouring pRP4 had a discrete plasmid band of $54 \mathrm{~kb}$ and a plasmid band whose migration suggested a plasmid of about $200 \mathrm{~kb}$ (lanes 9 and 8 respectively). A total of 63 transconjugants from three experiments, 13 from matings with strain M160-87pRP4 as donor and 50 from matings with strain M140-87pRP4 as donor, were shown to be resistant to kanamycin (Km) $40 \mu \mathrm{g} / \mathrm{ml}$, tetracycline (Tc) $40 \mu \mathrm{g} / \mathrm{ml}$, ampicillin (Ap) $100 \mu \mathrm{g} / \mathrm{ml}$ and streptomycin $500 \mu \mathrm{g} / \mathrm{ml}$, to require thiamine, threonine and leucine for growth on minimal medium and to be sensitive to phage $\mathrm{Pl}$, thus confirming them to be derivatives of strain $5 \mathrm{~K}$. All 63 transconjugants harboured the $6.9-\mathrm{kb}$ plasmid (not shown) and a presumptive pRP4 cointegrate form of about $200 \mathrm{~kb}$ (lanes 6 and 7). The $200-\mathrm{kb}$ plasmids were shown to be stable by plasmid profiling individual colonies from six successive platings of transconjugants on blood agar supplemented with kanamycin.

\section{Properties of the pRP4 co-integrate}

Two $5 \mathrm{~K}$ transconjugants harbouring the $200-\mathrm{kb}$ putative pRP4 co-integrate, designated $140 \cdot 2$ and $160 \cdot 2$, derived from matings with donors M140$87 \mathrm{pRP} 4$ and M160-87pRP4 respectively, were analysed further. To test whether the low frequency of transfer of pRP4 from isolates M140-87 and M160-87 to K12 was a property of the co-integrate plasmid, mating experiments were performed in which transconjugants $140 \cdot 2$ and $160 \cdot 2$ were donors and strain J62 was the recipient. Selection was made for transfer of each of the antibiotic resistances encoded by pRP4, separately. The frequency of transfer was about $1.4 \times 10^{-1}$ from both donors. Resistance to kanamycin, tetracycline and ampicillin were transferred en bloc as shown by replica plating and all J62 transconjugants tested harboured two plasmids, one of $200 \mathrm{~kb}$ and another of $6.9 \mathrm{~kb}$.

As a co-integrate form, the question arose as to which incompatibility functions of the two plasmids, pRP4 and the 145-kb cryptic plasmid would be dominant in any particular host. In an incompatibility experiment, transconjugants $140 \cdot 2$ and 160.2 were donors in matings with isolates $\mathrm{Ml40}$ 87 and M160-87, respectively, as recipients. It was thought that the co-integrate would enter the recipient and, if selection was made for pRP4encoded antibiotic resistances and the co-integrate remained stable, the incompatible cryptic plasmid would be lost. With $140 \cdot 2$ as donor and M140-87 as recipient, the frequency of transfer was $5.8 \times$ $10^{-4}$. Twenty-four kanamycin resistant transconjugants were shown by plasmid profiling to have

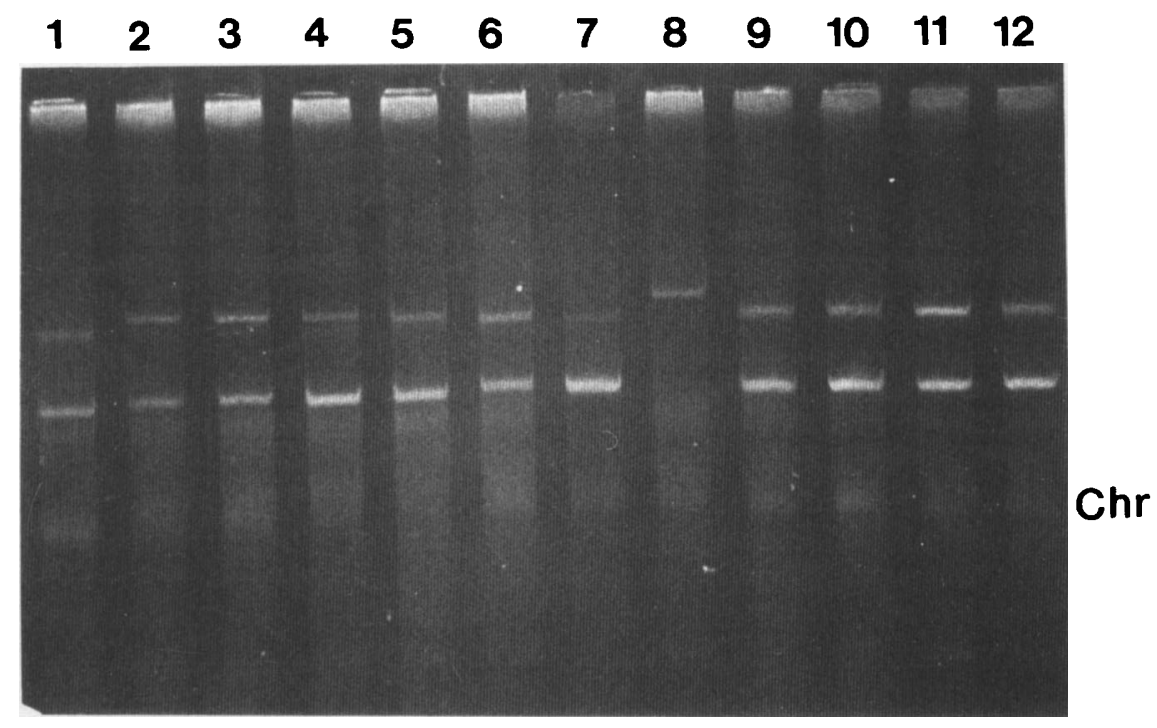

Fig. 3. Cell lysates of transconjugant $140 \cdot 2$ and derivatives run through agarose $0 \cdot 7 \%$ and visualised under UV transillumination after ethidium bromide staining: 140.2 $\mathrm{Ap}^{r} \mathrm{Tc}^{r} \mathrm{Km}^{\mathrm{r}}$ (lane 8); J62.1 $\mathrm{pR751} \mathrm{Tp}^{r}$ showing ccc and oc forms (lane 7); four 140.2 $\mathrm{Tp}^{\mathrm{r}}$ $A p^{s} \mathrm{Tc}^{\mathrm{s}} \mathrm{Km}^{\mathrm{s}}$ transconjugants derived from a mating with $\mathrm{J} 62.1 \mathrm{pR} 751 \mathrm{Tp}^{\mathrm{r}}$ as donor with selection for transfer of $\mathrm{Tp}^{\mathrm{r}}(\mathrm{pR} 751$ ) into 140.2 (lanes 9-12); and six 140.2 $\mathrm{Tp}^{r} \mathrm{Ap}^{\mathrm{r}} \mathrm{Tc}^{\mathrm{s}} \mathrm{Km}^{\mathrm{s}}$ transconjugants derived from a mating with $\mathrm{J} 62 \cdot 1 \mathrm{pR}^{2} \mathrm{Tp}^{\mathrm{T}} \mathrm{Tp}^{\mathrm{r}}$ as donor with selection for transfer of $\mathrm{Tp}^{r}(\mathrm{pR} 751)$ and retention of $\mathrm{TnA}\left(\mathrm{Ap}^{r}\right)$ in 140.2 (lanes 1-6). Chromosomal DNA is indicated by chr. 
the $200-\mathrm{kb}$ co-integrate plasmid, the $120-\mathrm{kb}$ cryptic plasmid and the $6 \cdot 9-\mathrm{kb}$ plasmid (not shown) but not the 145-kb cryptic plasmid (fig. 2, lanes 3 and 4). With transconjugant $160 \cdot 2$ as donor and isolate $\mathrm{M} 160.87$ as recipient, the frequency of transfer was $4 \times 10^{-4}$. Twenty-four kanamycin resistant transconjugants contained plasmids of $145 \mathrm{~kb}, 105 \mathrm{~kb}$, $54 \mathrm{~kb}$ (pRP4) and $6.9 \mathrm{~kb}$ (not shown) with a plasmid band corresponding to $200 \mathrm{~kb}$ (fig. 2, lanes 1 and 2) indicating resolution of the $200-\mathrm{kb}$ co-integrate plasmid in some but not all transconjugants.

In another incompatibility experiment, transconjugants 140.2 and 160.2 were used as recipients and the inc $\mathrm{P}$ plasmid, $\mathrm{pR} 751$, which encodes trimethoprim (Tp) resistance, was introduced by filter mating with strain $\mathrm{J} 62 \cdot 1 \mathrm{pR} 751$ as donor. Selections were made on trimethoprim $10 \mu \mathrm{g} / \mathrm{ml}$ alone or in combination with either, tetracycline $40 \mu \mathrm{g} / \mathrm{ml}$ or ampicillin $50 \mu \mathrm{g} / \mathrm{ml}$. In a control experiment, strains J62-1 pR751 and 5K were mated with selection for transfer of pR751 into $5 \mathrm{~K}$ on trimethoprim $10 \mu \mathrm{g} /$ $\mathrm{ml}$; the frequency of transfer was $5 \times 10^{-2}$. With transconjugant 140.2 as recipient, the frequency with which trimethoprim resistant transconjugants were obtained was $5.8 \times 10^{-4}$. Trimethoprim and ampicillin resistance transconjugants were obtained at a frequency of $7.3 \times 10^{-5}$. No trimethoprim- and tetracycline-resistant transconjugants were obtained. Fig. 3 shows plasmid profiles (excluding the $6 \cdot 9-\mathrm{kb}$ plasmid) of donor J62-1 pR751 (lane 7) in both ccc and oc forms, recipient $140 \cdot 2$ (lane 8), four trimethoprim-resistant transconjugants (lanes 9-12) and six trimethoprim- and ampicillin-resistant transconjugants (lanes 1-6). It would appear that in a K 12 background, incompatibility between pR751 and pRP4 in co-integrate form was demonstrated. When selecting for $\mathrm{pR} 751$ on trimethoprim alone, pRP4 excised from the cointegrate and was lost leaving the $145-\mathrm{kb}$ cryptic plasmid. However, with selection for both trimethoprim and ampicillin, excision of pRP4 from the co-integrate was imprecise as shown by the varying sizes of the residual cryptic plasmid presumably tagged with at least the bla gene of pRP4.

Derivatives of isolates M140-87 and M160-87 which had received the co-integrate (pRP4::145$\mathrm{kb}$ cryptic) plasmid by filter mating were used as donors in matings with $E$. coli $\mathrm{K} 12$ strain $5 \mathrm{~K}$ as recipient to test whether transfer functions had been restored. In these experiments, eight randomly chosen donors from each of isolates M140-87 and M160-87 were used with selection being made separately for ampicillin, tetracycline or kanamycin. The frequencies of transfer were in the range $8 \times 10^{-7}$ to $7 \times 10^{-8}$. Transfers of resistances were shown, by replica plating, to be en bloc and plasmid profiles of $5 \mathrm{~K}$ transconjugants revealed one plasmid of $200 \mathrm{~kb}$ and another of $6.9 \mathrm{~kb}$.

\section{Discussion}

E. coli of serogroup O138 showed considerable toxin gene polymorphism. Whilst the verocytotoxin is a significant factor in causing post-weaning diarrhoea and oedema disease (Nielsen, 1981; Marques et al., 1987), the contribution to the development of disease made by enterotoxins is unclear. The lack of known adhesins in these enterotoxigenic isolates suggests an inability to cause disease by the same mechanism as typical enterotoxigenic $E$. coli (ETEC) unless these isolates harbour a novel adherence mechanism. Whether O138 isolates lacking toxin genes altogether were pathogenic is not known, although Matthewson et al. (1985) have demonstrated a mild diarrhoeal disease caused by adherent non-toxigenic strains. It is tempting to speculate that toxin polymorphism is, at least in part, a reflection of the range of disease syndromes associated with $E$. coli $\mathrm{O} 138$ in pigs.

The toxin polymorphism displayed by serogroup O138 may be attributable to a dynamic interchange of toxin genes by plasmids, bacteriophages and transposons. However, the VT2 gene was chromosomal; whether the VT2 gene was integrated as part of a temperate bacteriophage as in O157:H7:VT2 ${ }^{+}$isolates (Willshaw et al., 1987) is not known. The VT2 gene was not mobilised by pRP4, a finding which confirms that of Gannon et al. (1988). Here may be evidence for derivation of $\mathrm{VT}^{+}$and $\mathrm{VT}^{-}$clones of serogroup $\mathrm{O} 138$.

Toxin-encoding plasmids have been known for some time (Smith et al., 1985) and may have been acquired recently as entire entities by individual O138 strains by conjugation. Alternatively, such plasmids may have been produced by co-integration of two or more toxin-gene bearing plasmids upon residence in 0138 strains. The possession of transmissible toxin plasmids suggests that serogroup $\mathrm{O} 138$ is a potential source for the dissemination of toxin genes to other bacteria.

The mechanism for repression of pRP4 transfer by two $\mathrm{O} 138$ isolates is unclear. However, repression was mediated through the cytoplasm and not as a result of co-integration affecting genetic function of pRP4 because transfer was still dramatically reduced even when the plasmids were resolved in an 0138 background. It is intriguing that escape from repression of transfer occurred at a very low frequency resulting in the production of a stable co-integrate in the recipient. In a K12 
background, the co-integrate plasmid behaved as plasmid RP4 with respect to mobility and incompatibility which suggests that the repression mechanism was only operative in an $\mathrm{O} 138$ background. Whether the repression mechanism was plasmid encoded, but not expressed in the co-integrate form in $\mathrm{K} 12$, or chromosomal is unknown. If the repression of transfer function was chromosomal then perhaps the common concept of plasmid promiscuity (Farrar, 1983; Thompson, 1986) needs to be reconsidered because the two isolates described here may have evolved a plasmid capture mechanism. It might explain plasmid and plasmidborne toxin gene polymorphism in $E$. coli serogroup O138. Other organisms such as $S$.typhimurium DT204C are known to readily accumulate plasmids (Wray et al., 1987) whereas others such as $S$. dublin and $S$. enteritidis generally carry a single plasmid (Woodward et al., 1989a,b). Of course, plasmid transfer and carriage depends upon ecological factors (Corpet, 1986) and plasmid polymorphism may be a reflection of the environment of $E$. coli O138 rather than their innate genetic makeup.

Clues to the mechanism of plasmid co-integration were gained by incompatibility experiments. Plasmid pRP4 encodes TnA (Tn3), a prototype for class II transposons (Kleckner, 1981) which are known to generate co-integrates as normal intermediates in transposition (Arthur and Sherratt, 1979). Ben-

\section{REFERENCES}

Anderson D G, Moseley S L 1988 Escherichia coli F41 adhesin: Genetic organisation, nucleotide sequence, and homology with the K88 determinant. Journal of Bacteriology 170: 4890-4896.

Arthur A, Sherratt D 1979 Dissection of the transposition process: a transposon-encoded site-specific recombination system. Molecular and General Genetics 175: 267-274.

Bennett P M, Heritage J, Comanducci A, Dodd H M 1986 Evolution of $\mathbf{R}$ plasmids by replicon fusion. Journal of Antimicrobial Chemotherapy 18 Suppl C: 103-111.

Birnboim H C, Doly J 1979 A rapid alkaline extraction procedure for screening recombinant plasmid DNA. Nucleic Acids Research 7: 1513-1523.

Colson C, Glover S W, Symonds N, Stacey K A 1965 The location of the genes for host-controlled modification and restriction in Escherichia coli K12. Genetics 52: 1043-1050.

Corpet D E 1986 Ecological factors influencing the transfer of plasmids in vitro and in vivo. Journal of Antimicrobial Chemotherapy 18 Suppl C: $127-132$.

Dallas W S, Gill D M, Falkow S 1979 Cistrons encoding Escherichia coli heat-labile toxin. Journal of Bacteriology 139: $850-858$

Dobrescu L 1983 New biological effect of edema disease principle (Escherichia coli-neurotoxin) and its use as an invitro assay for this toxin. American Journal of Veterinary Research 44: 31-34. nett et al. (1986) described replicon fusion by oneended transposition in which the co-integrate was not resolved, presumably associated with loss of the resolvase function, as would appear to be the case in this study. However, upon incompatible challenge of the co-integrate with R751, pRP4-encoded functions were lost en bloc indicating that resolvase was able to excise pRP4 from the co-integrate. Also, when the co-integrate was introduced into an O138 background, plasmid resolution was observed. Here was evidence that a resolvase capability, whether or not TnA-encoded, functioned in $\mathrm{K} 12$ and $\mathrm{O} 138$ backgrounds. Interestingly, in the incompatibility challenge experiments it was demonstrated that excision of pRP4 from the cointegrate was often imprecise, as evidenced by the retention of ampicillin resistance. Perhaps the active sites for excision recombination events were in or around $\operatorname{TnA}$, which encodes ampicillin resistance, which might be further evidence for intimate involvement of $\operatorname{TnA}$ in the initial cointegration. Notwithstanding a probable role for TnA in co-integration, the effect of a cryptic plasmid in an O138 background upon pRP4 behaviour was significant. This indicates a role of such cryptic plasmids for plasmid capture and cointegration in vivo; it is possible that multiple toxigenic plasmids have been formed by such cointegration events.
Farrar W E 1983 Molecular analysis of plasmids in epidemiologic investigation. Journal of Infectious Diseases 148: 1-6.

Feinberg A P, Vogelstein B 1983 A technique for radiolabelling DNA restriction endonuclease fragments to high specific activity. Analytical Biochemistry 132: 6-13.

Gannon V P, Gyles C L, Friendship R W 1988 Characteristics of verotoxigenic Escherichia coli from pigs. Canadian Journal of Veterinary Research 52: 331-337.

de Graaf F K, Krenn B E, Klaasen P 1984 Organisation and expression of genes involved in the biosynthesis of $\mathrm{K} 99$ fimbriae. Infection and Immunity 43: 508-514.

Karmali M A 1989 Infection of Verocytotoxin-producing Escherichia coli. Clinical Microbiology Reviews 2: 15-38.

Kleckner N 1981 Transposable elements in prokaryocytes. Annual Reviews of Genetics 15 : 341-404.

Lathe R. Hirth P, DeWilde M, Harford N, Lecocq J P 1980 Cell-free synthesis of enterotoxin of $E$. coli from a cloned gene. Nature 284 : 473-474.

Law D 1988 Virulence factors of enteropathogenic Escherichia coli. Journal of Medical Microbiology 26: 1-10.

Lee C H, Moseley S L, Moon H W, Whipp S C, Gyles C L, So M 1983 Characterisation of the gene encoding heat-stable toxin II and preliminary molecular epidemiological studies of enterotoxigenic Escherichia coli heat-stable toxin II producers. Infection and Immunity 42 : 264-268.

Linggood M A, Thompson J M 1987 Verotoxin production among porcine strains of Escherichia coli and its association 
with oedema disease. Journal of Medical Microbiology 24: 359-362.

Mainil J, Bex F, Couturier M, Kaeckenbeeck A 1985 Hybridization on bovine enterotoxigenic Escherichia coli with two heat-stable enterotoxin gene probes. American Journal of Veterinary Research 46: 2582-2584.

Maniatis T, Fritsch E F, Sambrook J 1982 Molecular cloning: a laboratory manual. Cold Spring Harbor Laboratory, Cold Spring Harbor, New York.

Marques L R M, Peiris J S M, Cryz S J, O'Brien A D 1987 Escherichia coli strains isolated from pigs with edema disease produce a variant of Shiga-like toxin II. FEMS Microbiology Letters 44: 33-38.

Matthewson J J et al. 1985 A newly recognised cause of travelers' diarrhea: enteroadherent Escherichia coli. Journal of Infectious Diseases 151 : 471-475.

Nielson N O 1981 Edema disease. In: Leman A D (ed) Diseases of swine. Iowa State University Press, Ames, pp 478-490.

Moseley S L, Huq I, Alim A R M A, So M, Samadpour-Motalebi M, Falkow S 1980 Detection of enterotoxigenic Escherichia coli by DNA colony hybridization. Journal of Infectious Diseases 142: 892-898.

Moseley S L, Dougan G, Schneider R A, Moon H W 1986 Cloning of chromosomal DNA encoding the F41 adhesin of enterotoxigenic Escherichia coli and genetic homology between adhesins F41 and K88. Journal of Bacteriology 167: 799-804.

Pugsley A P, Oudega B 1987 In Hardy K G (ed) Plasmids: a practical approach. IRL Press, Oxford, pp 105-161.

Smith H W, Green P, Parsell Z 1983 Vero cell toxins in Escherichia coli and related bacteria : transfer by phage and conjugation and toxic action in laboratory animals, chickens and pigs. Journal of General Microbiology 129: 3121-3137.

Smith H R, Scotland S M, Rowe B 1985 Genetics of Escherichia coli virulence. In: Sussman M (ed) The virulence of Escherichia coli: reviews and methods. Society for General Microbiology special publication, Academic Press, London, pp 227-269.
Smith H R, Scotland S M 1988 Vero cytotoxin-producing strains of Escherichia coli. Journal of Medical Microbiology 26: 7785.

Smith H R et al. 1988 Vero cytotoxin production and presence of VT genes in Escherichia coli strains of animal origin. Journal of General Microbiology 134 : 829-834.

Sojka W J 1965 Escherichia coli in domestic animals and poultry. Commonwealth Agricultural Bureaux, Farnham Royal, UK.

Sojka W J, Erskine R G, Lloyd M K 1957 Haemolytic Escherichia coli and "oedema disease" of pigs. Veterinary Record 69: 293-301.

Thompson R 1986 R Plasmid transfer. Journal of Antimicrobial Chemotherapy 18 Suppl C: 13-23.

Willshaw G A, Smith H R, Scotland S M, Rowe B 1985 Cloning of genes determining the production of vero cytotoxin by Escherichia coli. Journal of General Microbiology 131 : 30473053.

Willshaw G A, Smith H R, Scotland S M, Field A M, Rowe B 1987 Heterogeneity of Escherichia coli phages encoding vero cytotoxins: comparison of cloned sequences determining VT1 and VT2 and development of specific gene probes. Journal of General Microbiology 133: 1309-1317.

Woodward M J, McLaren I, Wray C, 1989a Genetic evidence for a chromosomally integrated multiresistance plasmid in Salmonella dublin. Journal of Medical Microbiology 28 : 205210.

Woodward M J, McLaren I, Wray C $1989 b$ Distribution of virulence plasmids within salmonellae. Journal of General Microbiology 135: 503-511.

Woodward M J, Kearsley R, Wray C, Roeder P L 1989c DNA probes for the detection of toxin genes in Escherichia coli isolated from diarrhoeal disease in cattle and pigs. (In press.)

Wray C, McLaren I, Parkinson N M, Beedell Y 1987 Differentiation of Salmonella typhimurium DT204C by plasmid profile and biotype. Veterinary Record 121 : 514516. 